\title{
SODIUM BICARBONATE SUPPLEMENTATION IMPROVES PERFORMANCE IN ISOMETRIC FATIGUE PROTOCOL
}

\author{
A SUPLEMENTAÇÃO DE BICARBONATO DE SÓDIO MELHORA O DESEMPENHO EM PROTOCOLO \\ DEFADIGA ISOMÉTRICO
}

Original Article Artigo Original Artículo Original

\section{LASUPLEMENTACIÓN DE BICARBONATO DE SODIO MEJORA EL DESEMPEÑO EN PROTOCOLO DEFATIGAISOMÉTRICO}

\begin{abstract}
Cezar Augusto Souza Casarin' (Physical Education Professional) Rafael Ambrósio Battazza² (Physical Education Professional) Marco Aurélio Lamolha ${ }^{2}$ (Pharmacist)

Marcelo Martins Kalytczak' (Physical Education Professional) Fabiano Politti'

(Physiotherapist)

Alexandre Lopes Evangelista (Physical Education Professional) Andrey Jorge Serra ${ }^{3}$ (Physical Education Professional) Roberta Luksevicius Rica ${ }^{2}$ (Physical Education Professional) Marcos Rodolfo Ramos Paunksnis (Physical Education Professional) Caue Vazquez La Scala Teixeira ${ }^{4}$ (Physical Education Professional) Aylton Figueira Junior ${ }^{5}$

(Physical Education Professional) Danilo Sales Bocalini ${ }^{6}$

(Physical Education Professional)
\end{abstract}

1. Universidade Nove de Julho (UNINOVE), Graduate Program in Rehabilitation Sciences, São Paulo, SP, Brazil.

2. Universidade São Judas Tadeu (USJT), Graduate Program in Physical Education, Translational Physiology Laboratory, São Paulo, SP, Brazil. 3. Universidade Federal de São Paulo- Escola Paulista de Medicina, Department of Medicine, São Paulo, SP, Brazil.

4. Faculdade Praia Grande, Department of Physical Education, Praia Grande, SP, Brazil.

5. Universidade São Judas Tadeu (USJT), Graduate Program in Physical Education, São Paulo, SP, Brazil. 6. Universidade Federal do Espirito Santo, Physiology and Experimental Biochemistry Laboratory of Physical Education Sport Center, Vitoria, ES, Brazil.

\section{Correspondence:}

Danilo Sales Bocalini. Universidade Federal do Espirito Santo.

Rua Militao Barbosa de Lima, 132, Centro, São Bernardo do Campo, SP, Brazil. 09720-420.

bocaliniht@hotmail.com

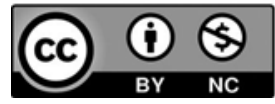

\begin{abstract}
Introduction: Although sodium bicarbonate ( $\mathrm{NaHCO} 3$ ) supplementation has been shown to decrease fatigue and improve high-intensity exercise performance, the effects on maintenance of isometric contractions are not clear. Objective: To investigate the effect of $\mathrm{NaHCO} 3$ on the performance of individuals subjected to a fatigue protocol in an isometric exercise on the isokinetic dynamometer. Methods: Participants were 12 men in a randomized, double-blind, crossover, placebo-controlled trial. Sixteen minutes after the intake of $0.3 \mathrm{~g} / \mathrm{kg}$ of body mass of $\mathrm{NaHCO} 3$ or placebo, the participants performed an isometric fatigue protocol of right knee extension exercises during eight minutes at $70 \%$ of maximum voluntary isometric contraction. The fatigue indicator was the time point at which torque was reduced to $50 \%$ of the initial value. The length of resistance was assessed by maintaining the task over $50 \%$ of the initial torque. Lactate/blood pH concentrations and rate of perceived exertion (RPE) and pain (RPP) indexes were analyzed. The RPE of the session was evaluated 30 minutes after the test. Results: Blood pH was higher in pre-protocol and in the fatigue indicator after NaHCO3 intake, as were the blood lactate concentrations in the fatigue indicator and at the end of the protocol $(p<0.001)$. NaHCO3 supplementation increased the time to fatigue and lessened the rate of decline of isometric peak torque at the end of the protocol $(p<0.001)$. RPE and RPP were smaller at the end of the protocol in the NaHCO3 condition, and the RPE of the session was diminished $(p<0.001)$. Conclusion: NaHCO3 supplementation enhances steady isometric contraction performance and reduces the internal load. Level of Evidence II; Diagnostic studies - Investigation of an examination for diagnosis.
\end{abstract}

Keywords: Muscle fatigue; Sodium bicarbonate; Alkalosis; Exercise.

\section{RESUMO}

Introdução: A suplementação de bicarbonato de sódio (NaHCO3) tem demonstrado atenuar a fadiga e melhorar o desempenho do exercício de alta intensidade, mas os efeitos sobre a manutenção de contrações isométricas são pouco claros. Objetivo: Investigar o efeito do NaHCO3 no desempenho de indivíduos submetidos ao protocolo de fadiga em exercício isométrico no dinamômetro isocinético. Métodos: Doze homens participaram do estudo randomizado, duplo-cego, cruzado e controlado por placebo. Sessenta minutos após ingestão de 0,3 g/kg de massa corporal de $\mathrm{NaHCO}$ ou placebo, os participantes realizaram protocolo isométrico de fadiga dos extensores do joelho direito, com duração de oito minutos, a 70\% da contração isométrica voluntária máxima. Foi considerado indicador de fadiga o momento em que o torque aplicado diminuiu para 50\% do valor inicial. A duração da resistência foi avaliada com a manutenção da tarefa acima de 50\% do torque inicial. As concentrações de lactato e pH do sangue, assim como os índices de percepção subjetiva de esforço (PSE) e dor (PSD) foram analisados. A PSE da sessão foi avaliada 30 minutos após o teste. Resultados: O pH sanguíneo foi maior pré-protocolo e no indicador de fadiga após ingestão de NaHCO3, assim como as concentrações de lactato sanguíneo no indicador da fadiga e ao final do protocolo ( $p<$ 0,001). A suplementação de NaHCO3 aumentou o tempo para atingir a fadiga e atenuou o declínio do pico de torque isométrico no final do protocolo $(p<0,001)$. A PSE e PSD foram menores ao final do protocolo com NaHCO3 e a PSE da sessão foi atenuada $(p<0,001)$. Conclusão: A suplementação de NaHCO3 melhora o desempenho de contrações isométricas sustentadas e atenua a carga interna. Nível de Evidência Il; Estudos diagnósticos - Investigação de um exame para diagnóstico.

Descritores: Fadiga muscular; Bicarbonato de sódio; Alcalose; Exercício.

\section{RESUMEN}

Introducción: La suplementación de bicarbonato de sodio (NaHCO3) ha demostrado atenuar la fatiga y mejorar el desempeño del ejercicio de alta intensidad, pero los efectos sobre el mantenimiento de contracciones isométricas son poco claros. Objetivo: Investigar el efecto de NaHCO3 en el desempeño de individuos sometidos al protocolo de fatiga en ejercicio isométrico en el dinamómetro isocinético. Métodos: Doce hombres participaron del estudio aleatorizado, doble ciego, cruzado y controlado por placebo. Sesenta minutos después de la ingestión de 0,3 g/kg de masa corporal de NaHCO3 o placebo, los participantes realizaron protocolo isométrico de fatiga de los extensores de la rodilla derecha 
con duración de ocho minutos a 70\% de la contracción isométrica voluntaria máxima. Se consideró indicador de fatiga el momento en que el torque aplicado disminuyó para $50 \%$ del valor inicial. La duración de la resistencia fue evaluada con el mantenimiento de la tarea por encima del 50\% del torque inicial. Fueron analizadas las concentraciones de lactato y pH sanguíneos, así como lo índices de percepción subjetiva de esfuerzo (PSE) y dolor (PSD). La PSE de la sesión fue evaluada 30 minutos después del test. Resultados: El pH sanguíneo fue mayor pre-protocolo y en el indicador de fatiga después de la ingestión de $\mathrm{NaHCO}$, así como las concentraciones de lactato sanguíneo en el indicador de la fatiga y al final del protocolo ( $p<0,001)$. La suplementación de NaHCO3 aumentó el tiempo para alcanzar la fatigay atenuó el declive del pico de torque isométrico al final del protocolo ( $p<0,001)$. La PSE y PSD fueron menores al final del protocolo con NaHCO3 y la PSE de la sesión fue atenuada ( $p<0,001)$. Conclusión: La suplementación de NaHCO3 mejora el rendimiento de las contracciones isométricas sostenidas y atenúa la carga interna. Nivel de Evidencia ll; Estudios diagnósticos - Investigación de un examen para diagnóstico.

Descriptores: Fatiga muscular; Bicarbonato de sodio; Alcalosis; Ejercicio.

\section{INTRODUCTION}

Muscular fatigue (MF) is a complex, multifactorial phenomenon and, depending upon the task done, with various mechanisms that could impact on the strength reductionmagnitude. ${ }^{1,2}$ Specifically, in the high-intensity exercises with the predominance of the glycolytic system, the high hydrolysis of ATP results in the increasing of hydrogen ions concentrations ([ $\left.\left.\mathrm{H}^{+}\right]\right)$followed by a pH decreasing. This condition is named metabolic acidosis and could lead to a series of mechanisms affecting the contraction-relaxation muscle's process and, consequently, could be considered as an important MF indicator. ${ }^{3,4}$ Although MF is understood as a decrement in the ability to yield strength and muscular strength, when the task involves supporting a maximum contraction, the performance decrease is parallel to MF increase. Nevertheless, when the exercise asks for submaximal contractions, it is possible that the emergence of MF will not be associated with the effort interruption. As many activities in daily life and many exercise modalities involve submaximal contractions, the arising of MF could not be a limitation to the ability of an individual to perform the exercise, which means that submaximal contractions could be kept after the beginning of MF.'

In this sense, the use of alkaline substances has been widely employed in various sports modalities and high-intensity exercise protocols, trying to improve the performance by decreasing MF.-9 The sodium bicarbonate (NaHCO3) intake increases the blood concentration of sodium bicarbonate, which favors the $\mathrm{H}^{+}$and lactate efflux of the muscle cell and, in this way, decelerate the acidification process. ${ }^{10,11}$

A series of studies ${ }^{5-9}$ have shown that the intake of $\mathrm{NaHCO} 3$ improve the performance in high-intensity exercises, mainly the ones of intermittent nature, although other researchers have found divergent results. ${ }^{12-14}$

Amongst these factors, the use of ergogenic substances in isometric exercises has been poorly evaluated. ${ }^{15-17}$ Maughanet al. ${ }^{17}{ }^{17}$ assessing the effects of alkalosis induced by $\mathrm{NaHCO} 3$ intake in the exercise performance in healthy people, found a significantly increase in performance on loads related to $20 \%$, but not to 50 and $80 \%$ of the maximal voluntary contraction of knee extenders. Hunter et al., ${ }_{1}^{16}$ found a lower reduction of strength during the maximal sustained contraction of 50 s after an extended cycling exercise with individuals trained in the modality when $\mathrm{NaHCO} 3$ was used compared to the placebo.

Researches on the use of $\mathrm{NaHCO} 3$ are concentrated in intermittent, dynamic and short duration exercises. The knowledge and the study of the action of this substance in long duration continuous isometric contraction, and of the conditions related to MF in this particular type of exercise, may contribute to the use of strategies that could reduce this phenomenon and, consequently, to improve the performance of the task. ${ }^{18}$ Thus, the objective of this study was to investigate the effect of NaHCO3intake in the performance of healthy individuals submitted to a fatigue protocol in an isometric exercise in the isokinetic dynamometer.

\section{METHODS}

After approved by the local ethics committee of Sao Judas Tadeu University, (number 786.06) and have signed the Declaration of Helsinki, 12 healthy male volunteers wererecruited to participate in the study. All subjects have experience in resistance training (more than sixmonths) and no previous injuries of the lower limbs.

All subjects went to the laboratory three times to be familiar with the procedures to perform an isokinetic evaluation by using a Biodex System 3 (Biodex, Inc., Shirley, NY) and for signing all documents. Briefly, on the first day, the subjects signed consent forms and were submitted to the familiarization process of isometric test. On the second day, the anthropometric data (height, weight and skin folds) were evaluated and a second familiarization process set was performed. On the third day, the subjects were submitted to the last familiarization procedure set. All subjects performed three maximal isometric voluntary contractions (MIVC) on the right knee extensors at $90^{\circ}$ during five seconds and had five minutes rest between contractions to determine the maximal torque before the isometric fatigue protocol. After MIVC all subjects had to perform a high-level contraction (70\% maximal voluntary contractions) maintained until eight minutes or exhaustion. During test, the volunteers were verbally encouraged to keep the force level for as long as possible, until the force value decreased to $50 \%$ of MIVC (fatigue indicator). The endurance time was evaluated (time for which a subject can maintain the requested mechanical task 50\%above of MIVC).

After completing the familiarization test, the subjects were assigned in a double-blind,randomized, crossover design to consume $0.3 \mathrm{~g} / \mathrm{kg}$ body mass of $\mathrm{NaHCO} 3$ or Placebo (calcium carbonate - $\mathrm{CaCO} 3$ ). The $\mathrm{NaHCO} 3$ was evenly distributed in gelatin capsules 60 min before exercise according to the previous studies ${ }^{5}$ and separated by at least one week of washout.

Height was measured by a Cardiomed (WCS model) stadiometer, with an accuracy of $115 / 220 \mathrm{~cm}$. The measurement was performed with the cursor at an angle of $90^{\circ}$ on the scale, with the patient in a standing position with feet together in contact with Stadiometer. Total body mass was measured by a calibrated Filizola electronic scale (Personal Line Model 150) with a $100 \mathrm{~g}$ scale and a maximum capacity of $150 \mathrm{~kg}$. Body mass index $\left(\mathrm{BMI}, \mathrm{kg} / \mathrm{m}^{2}\right)$ was calculated using the equation $\mathrm{BMI}=$ weight/height. $^{2}$

To determine blood lactate concentration ([La- $]$ ) and $\mathrm{pH}$, blood samples were collected from the earlobe at predetermined points throughout each test. The $25-\mu \mathrm{L}$ samples were immediately evaluated by electrochemical analysis in an automated device (YSI 2300,Yellow Springs, OH) and blood gas analyser (i-STAT) respectively.

Subjective rate of perceived exertion (RPE) and pain (RPP) feelings were reported before, on fatigue point and immediately after fatigue protocol (end effort) using a 0-10 Borg scale and visual analog scale, respectively. ${ }^{19}$ 
The internal training load for each session was evaluated by multiplication of the exercise session duration in minutes by the training intensity, indicated by the RPE through the scale according to the previous studies. ${ }^{20}$ The subjects were told to choose a describer and a number from 0 to 10. To guarantee that the RPE mean data obtained refers to the total training, the subjects were asked to answer the following question 20 to 30 minutes after the end of the session: "How was your training today?".

The D'Agostino-Pearson test was applied to the Gaussian distribution analysis. The paired Student's t-test and One-way ANOVA followed by Bonferroni's post hoc test were performed to compare differences in fatigue protocol. Comparison analysis between inactive and active groups was performed by a repeated-measures ANOVA, followed by Bonferroni's post hoc test. Cohen's effect sizes were calculated, and evaluated based on the following criteria proposed by Rhea: ${ }^{21}<0.50$ trivial, 0.50 to 1.25 small, 1.25 to 1.9 moderate and $>2$ large. An alpha of 0.05 was used to determine statistical significance. All data values were expressed as mean \pm standard deviation. All analyses were performed using SPSS software (v 15.0; IBM, Armonk, NY, USA).

\section{RESULTS}

Mean values and standard deviation of the anthropometric parameters can be seen in Table 1.

The analysis of the effects of $\mathrm{NaHCO} 3$ supplementation did not show significantly differences between placebo and $\mathrm{NaHCO} 3$ in the variables isometric peak of torque (PT) (Placebo: $321 \pm 15$; NaHCO3: $321 \pm 18 \mathrm{Nm}$ ) and torque development rate (Placebo: $73 \pm 3$; NaHCO3: $76 \pm 4$ Nm/s) as described on Figure $1 \mathrm{~A}$ and $1 \mathrm{~B}$ respectively.

Significantly difference were not found on isometric PT corresponding to $50 \%$ of the maximum peak among the interventions (Figure $2 \mathrm{~A}$ ). However, in the end effort, the NaHCO3 (Fatigue: $160 \pm 23 \mathrm{Nm}$; End of protocol: $55 \pm 23 \mathrm{Nm}$ ) supplementation induced an improvement in the isometric PT maintenance when compared to the placebo intervention (Fatigue: $160 \pm 20 \mathrm{Nm}$; End effort: $16 \pm 8 \mathrm{Nm}$ ). A great effect size was found in both interventions (Placebo: 7.20; $\mathrm{NaHCO} 3$ : 4.56), although the $\mathrm{NaHCO} 3$ supplementation induced a smaller effect when compared to the placebo. The $\mathrm{NaHCO} 3$ supplementation promoted greater maintenance of isometric PT (Figure 2B), delaying $(p<0.001)$ the time (Placebo: $42 \pm 5 \mathrm{sec}$; NaHCO3: $95 \pm 5 \mathrm{sec}$ ) to reach fatigue with great effect size (10.6).

In figure 3B it is shown that significantly differences $(p<0.001)$ in [La-] were found in the Placebo intervention (Rest: 1.08 \pm 0.37 ; Fatigue: $4.47 \pm 1.51$; end effort: $6.92 \pm 1.13$ ) as well with NaHCO3 (Rest: $0.95 \pm 0.24$; Before: $5.42 \pm 1.63$; After: $7.71 \pm 0.74$ ) and great effect size in both interventions (Placebo: 15.78; NaHCO3: 28.16). However, the NaHCO3 induced hyperlactecemia both in fatigue and in the end of protocol when compared to the placebo.

Table 1. Mean and standard deviation (SD) of the biometrics parameters.

\begin{tabular}{c|c|c}
\hline & Mean \pm SD & $95 \% \mathbf{C l}$ \\
\hline Age (years) & $32 \pm 8$ & $24.96-39.04$ \\
\hline Body mass $(\mathrm{kg})$ & $81 \pm 4$ & $77.44-83.99$ \\
\hline Height $(\mathrm{m})$ & $1.74 \pm 0.1$ & $1.69-1.79$ \\
\hline BMl $\left(\mathrm{kg} / \mathrm{m}^{2}\right)$ & $27 \pm 2$ & $25.14-28.29$ \\
\hline Body fat $(\%)$ & $21 \pm 7$ & $14.94-27.06$ \\
\hline Fat mass $(\mathrm{kg})$ & $17 \pm 6$ & $11.74-22.83$ \\
\hline Lean mass $(\mathrm{kg})$ & $63 \pm 5$ & $59.00-67.86$ \\
\hline
\end{tabular}

BMI: body mass index, IC: confidance interval.
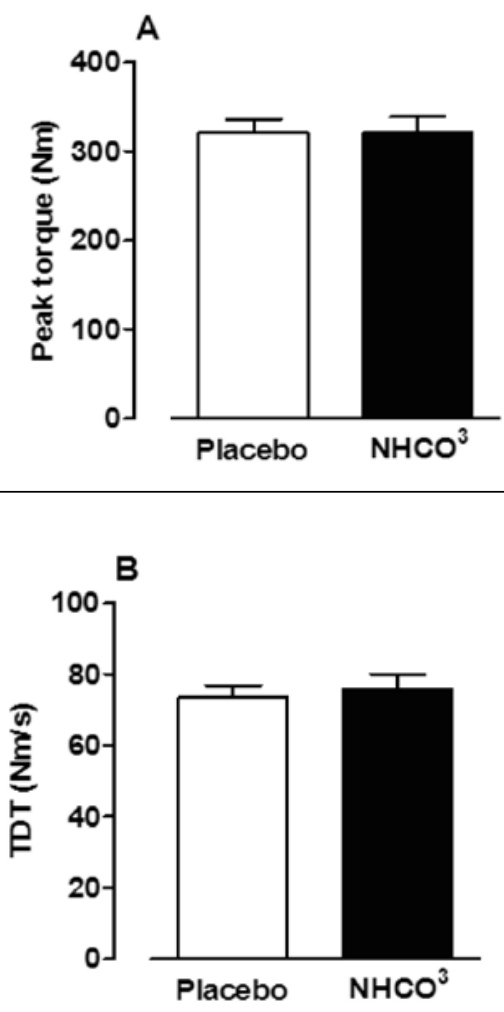

Figure 1. Mean and standard error of isometric peak of torque (Panel A) and torque development rate (Panel B).

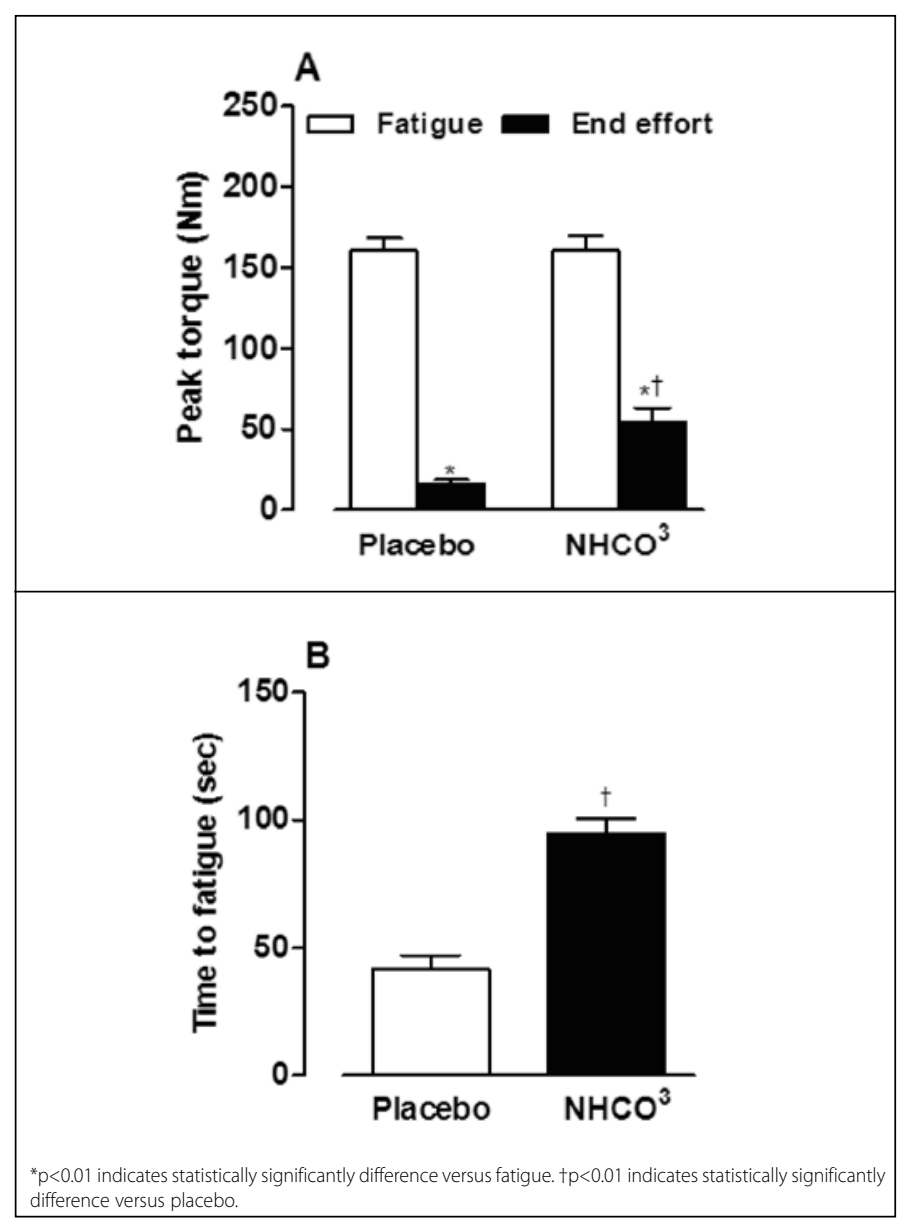

Figure 2. Mean and standard error of the peak of isometric torque at 50\% of the isometric peak of torque (fatigue) and at the end of protocol (Panel A) and the time of sustaining strength till reach $50 \%$ of isometric peak of torque (Panel B). 


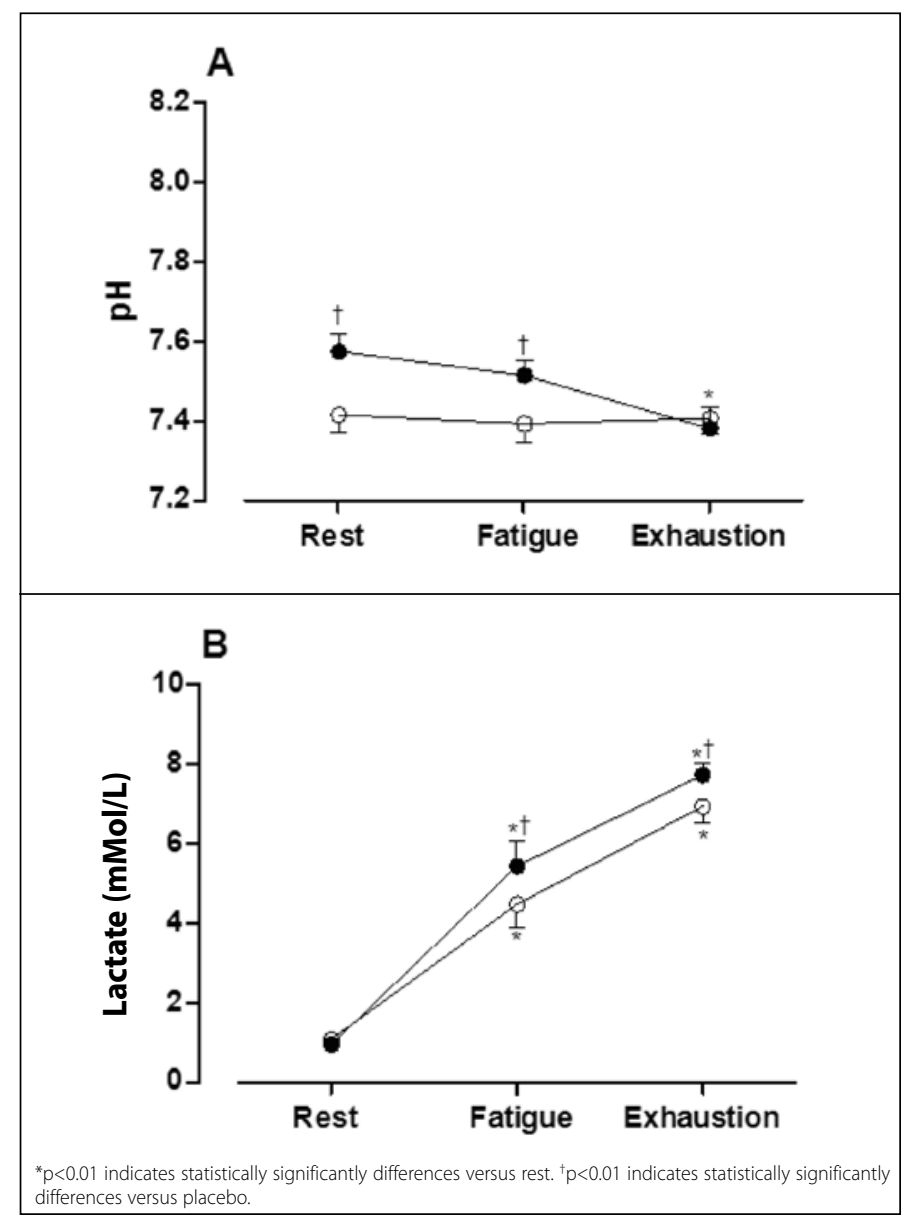

Figure 3. Mean and mean standard deviation of $\mathrm{pH}$ at $50 \%$ of the isometric peak of torque and the blood lactate concentration in interventions with Placebo (o) e NHCO3 (

Significantly differences $(p<0.001)$ found in the intervention with placebo in RPE (Fatigue: $6.14 \pm 1.77$; End effort: $9.28 \pm 1.89$ ) as well as RPP (Fatigue: $7.28 \pm 9.85$; End effort: $9.85 \pm 0.37$ ) and great effect size was found in both parameters (1.77 and 1.40) respectively. Similar results were found in RPE after the NaHCO3 intake (Fatigue: $5.71 \pm 1.88$ < End effort: $7.85 \pm 1.95$ ) as well as in RPP (Fatigue: $5.28 \pm 7.85<$ End effort: $7.85 \pm 1.95$ ) and the great effect size was found in both parameters (1.13 and 0.32). In addition, the $\mathrm{NaHCO} 3$ supplementation induced lower $(p<0,001)$ RPE (Figure 4A) and RPP (Figure 4B) when compared to placebo.

It was found significantly difference $(p<0.001)$ among the internal load in the both interventions (Placebo: $74.29 \pm 6.04$; NaHCO3: $56.0 \pm$ 6.53 arbitrary units), considering the parameters more commonly used in the training prescription (Figure 5).

\section{DISCUSSION}

The main findings of this study correspond to the significantly increase in the time to reach fatigue ( $50 \%$ of initial PT) and a smaller reduction of isometric PT at the end of protocol after the $\mathrm{NaHCO} 3$ supplementation. This result shows the ergogenic effect in the maintenance of the isometric strength assessed in the isokinetic dynamometer. The improvement in the exercise performance observed in this study follows other studies, $9,6,22-24$ with improvement in the performance after alkalosis induction.

It is known that the fatigue process is a multifactorial phenomenon, however in high-intensity exercises, MF is associated with the increase of $\left[\mathrm{H}^{+}\right]$with a simultaneous decrease in the intramuscular $\mathrm{pH}^{3}$. The best performance found after the $\mathrm{NaHCO} 3$ intake probably is linked to the increase of the $\mathrm{H}^{+}$efflux of the muscle in exercise, which decreases the intramuscular acidosis and thus delays the fatigue. ${ }^{10}$

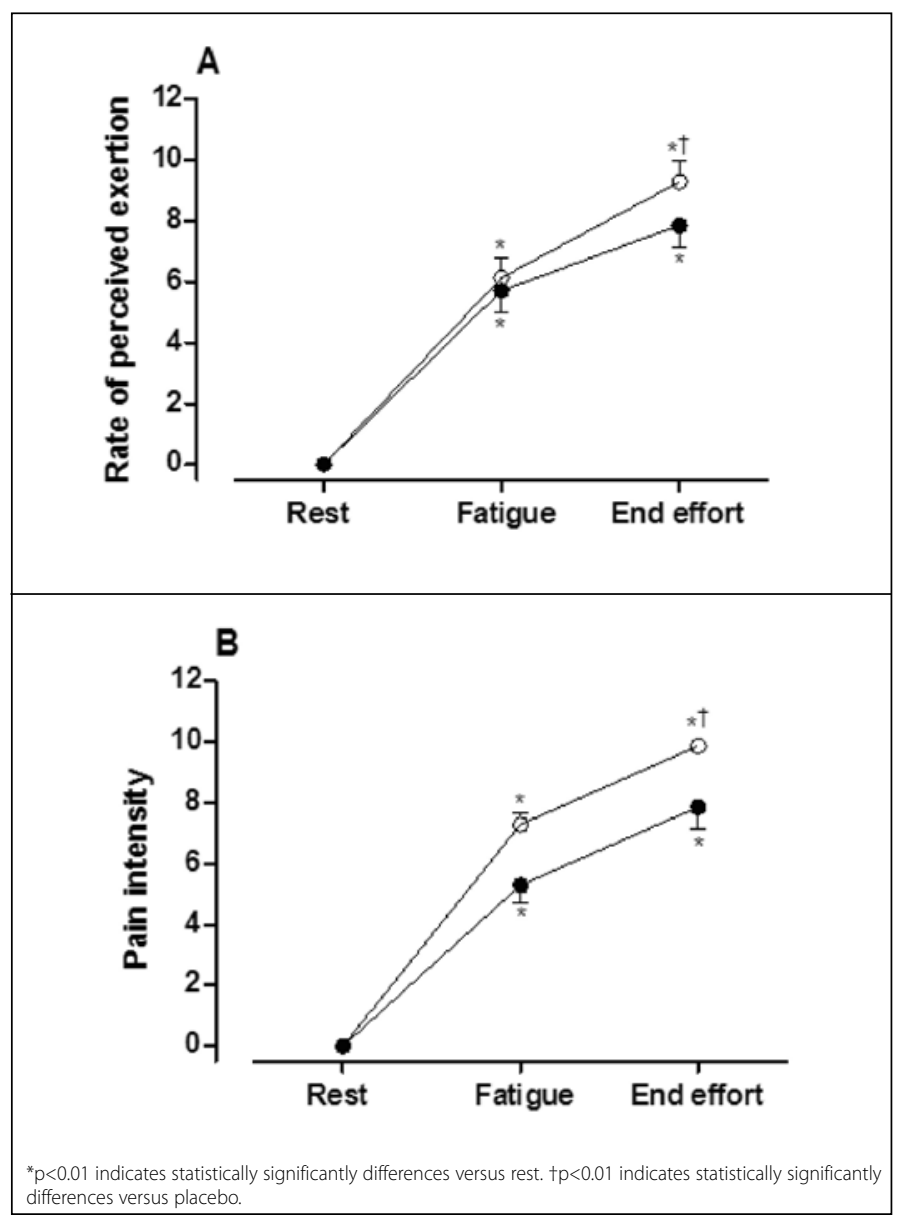

Figure 4. Mean \pm standard deviation of rate of perceived exertion (Panel A) and pain (Panel B) in the interventions with Placebo (o) e $\mathrm{NHCO} 3(\bullet)$

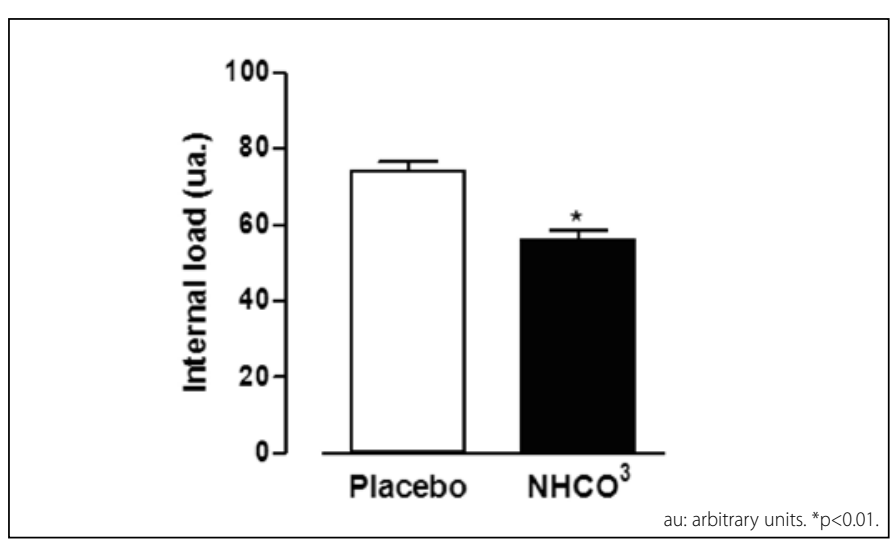

Figure 5. Mean \pm standard deviation of internal load in the interventions with Placebo (o) and $\mathrm{NHCO} 3(\bullet)$

The efflux of $\mathrm{H}^{+}$from the cell into the extra cell is influenced by the $\mathrm{pH}$ gradient and occurs together with the lactate efflux, undertaken through the monocarboxylate transporter protein linked to the plasma membrane. Thus, the higher extracellular $\mathrm{pH}$ values pre-exercise and in the bout of fatigue observed after the $\mathrm{NaHCO} 3$ intake suggest that the $\mathrm{H}^{+}$speed of transportation was increased as a consequence of the higher $\mathrm{pH}$ gradient resulting from the alkaline substanceintake..$^{25}$

Although increase in the blood [La-] has been observed during the implementation of the protocol both after $\mathrm{NaHCO} 3$ and placebo when compared to the pre-exercise a higher efflux of lactate was observed in the bout of fatigue and at the end of protocol, when the participants were supplemented with $\mathrm{NaHCO}$. In turn, the increased lactate efflux contributes to the intramuscular $\mathrm{pH}$ maintenance and, thus, to the 
intensity of the exercise ${ }^{25}$. As suggested by Coombes and McNaugthon, 22 the higher values of blood [La-] could reflect on a higher anaerobic contribution during the exercise and a higher dependence of anaerobic glycolysis to complete the protocol in the $\mathrm{NaHCO} 3$ essay.

Consistently, has been demonstrated that the intake of $0.3 \mathrm{~g} . \mathrm{kg} /$ body mass of $\mathrm{NaHCO} 3$ increases both the pre-exercise extracellular $\mathrm{pH}$ and the blood [La-] during theeffort. 5,7-9,13,14

In connection with the initial PT and the torque development rate conducted in the MIVC test (pre-protocol, eight minutes), statistical differences were not observed between the two conditions, pointing out that the maximum strength was not affected by the NaHCO3. One possible explanation for this is that, due to the short duration of the effort (three contractions of five seconds), a significant production of $\mathrm{H}+$ did not occur, since in this type of effort the primary transfer channel is ATP-CP and not the glycolytic one. In this sense, the NaHCO3action is unable to affect the performance. ${ }^{22}$

The alkalosis effect in the effort perception has been investigated in research of various modalities of exercise, ${ }^{5,6,26}$ but the results are conflicting. Krustrup et al. ${ }^{5}$ found smaller values for only after $440 \mathrm{~m}$ in an intermittent test of high intensity, but not after 160 and $280 \mathrm{~m}$, and in the moment of exhaustion after NaHCO3supplementation when compared to the control. Nevertheless, when the participants ingested the alkaline substance, there was an improvement of $14 \%$ in the performance. In turn, Duncan et al. ${ }^{26}$ did not find differences in the RPE between $\mathrm{NaHCO} 3$ and control of trained men in resistance exercise, although there was a higher number of repetitions in the first exercise after the use of $\mathrm{NaHCO}$.

In our study, we did not find alterations in the effort perception in the bout of fatigue. However, a lesser degree of RPE was established after the eight minutes of protocol. In theory, we can suggest that centrally mediated mechanisms could be affected. Among these mechanisms, has been proposed that the metabolic alterations in the muscle in exercise result in inhibitory neural feedback through afferent fibers from groups III and IV, which are responsive to a range of chemical stimuli.5,27 Thus, the smaller RPE and the higher performance with $\mathrm{NaHCO} 3$, could reflect a smaller metabolic alteration (including $\left[\mathrm{H}^{+}\right]$) due to the action of this substance and, consequently, a less negative muscular feedback and a smaller effect on the descending central command for the motor neurons. ${ }^{27}$ However, it is interesting to note that at the end of protocol (when the RPE was smaller in $\mathrm{NaHCO} 3$ ) pH values were not different between $\mathrm{NaHCO} 3$ and placebo. The investigation of other metabolic variables could help to understand this phenomenon.

Concerning the RPE's session performed after 30 minutes after the end of the protocol, smaller values were observed when the participants were supplemented with $\mathrm{NaHCO} 3$. The session's RPE has been proposed as a valid method to monitor the exercise's intensity and allows the individual to give a global assessment about how difficult the session was. ${ }^{20}$ As per our knowledge, till now there is not a research investigating the influence ofNaHCO3 in the answers of RPE's session. Again, it is possible that smaller metabolic alterations have occurred during the exercise in function of the higher extracellular buffered after the NaHCO3 intake, which could be contributed for a full recovery and as maller perception of effort after 30 minutes of recovery. ${ }^{27}$

\section{CONCLUSION}

The results suggest that the $\mathrm{NaHCO} 3$ intake could improve the performance of sustained isometric contractions of knee extensors with decrease in the RPE e RPP and a smaller load. However, it is needed to conduct more research to investigate the $\mathrm{NaHCO} 3$ effect in the internal load parameters, as, in the RPE's session, which can give information related to the recovery and help in the exercise of dynamic characteristics prescription.

All authors declare no potential conflict of interest related to this article

AUTHORS' CONTRIBUTIONS: Each author made significant individual contributions to this manuscript. CASC (0000-0002-3606-0828)* conceived the study, acquired and interpreted data, and drafted the manuscript. RAB (0000-0001-9874-3790)* interpreted data, and drafted and reviewed the manuscript. MAL: analyzed data and reviewed the manuscript. MMK (0000-0002-2406-4450)* analyzed data and reviewed the manuscript. FP (0000-0002-7901-3351)* interpreted data, and drafted and reviewed the manuscript. ALE (0000-00024941-6475)*, MRRP (0000-0003-1857-6924 interpreted data, and drafted and reviewed the manuscript. AJS (0000-0002-5407-8183)* analyzed data and reviewed the manuscript. RLC (0000-0002-6145-1337)*, AFJ (0000-0001-8069-2366)*, CVLST (0000-0002-8523-5794) interpreted data, and drafted and reviewed the manuscript. DSB (0000-0003-3993-8277)* conceived the study, acquired and interpreted data, and reviewed the manuscript. *ORCID (Open Researcher and Contributor ID).

\section{REFERENCES}

1. Enoka RM, Duchateau J. Muscle fatigue what, why and how it influences musclefunction. J Physiol. 2008;586(1):11-23.

2. Taylor $\mathrm{JL}$, Gandevia SC. A comparison of central aspects of fatigue in submaximal and maximal voluntary contractions. J Appl Physiol. 2008;104(2):542-50

3. Fitts RH. Cellular mechanisms of muscle fatigue. Physiol Rev. 1994;74(1):49-94.

4. Ament W, Verkerke, GJ. Exercise and fatigue. Sports Med. 2009;5(39):389-422.

5. Krustrup $P$, Ermidis $G$, Mohr M. Sodium bicarbonate intake improves high-intensityintermittent exercise performance in trained young men. J Int Soc Sports Nutr. 2015;12(25):1-7.

6. Artioli GG, Gualano B, Coelho DF, Benatti FB, Galley AW, Lancha AH. Doessodium-bicarbonate ingestion improve simulated judo performance? Int J Sport Nutr Exerc Metab. 2007;17(2):206-17.

7. Zajac A, Cholewa J, Poprzecki S, Waskiewicz Z, Langfort J. Effects of sodiumbicarbonate ingestion on swim performance in youth athletes. J Sports Sci Med. 2009;8(1):45-50.

8. Wu CL, Shih MC, Yang CC, Huang MH, Chang CK. Sodium bicarbonate supplementation prevents skilled tennis performance decline after a simulated match. J Int Soc Sports Nutr. 2010;7(33):1-8.

9. Carr BM, Webster MJ, Boyd JC, Hudson GM, Scheett TP. Sodium bicarbonatesupplementation improves hypertrophy-type resistance exercise performance Eur J Appl Physiol. 2013;113(3):743-52.

10. McNaughton LR, Siegler JC, Midgley A. The ergogenic effect of sodium bicarbonate. Curr Sport Med Rep. 2008;7(4):230-6.

11. Burke LM, Pyne DB. Bicarbonate loading to enhance training and competitiveperformance. Int J Sport Physiol Perform. 2007;2(1):93-7.

12. Webster MJ, Webster MN, Crawford RE, Gladden LB. Effect of sodium bicarbonateingestion on exhaustive resistance exercise performance. Med Sci Sport Exerc. 1993;25(8):960-5.

13. Portington KJ, Pascoe DD, Webster MJ, Anderson LH, Rutland RR, Gladden LB. Effectof induced alkalosis on exhaustive leg press performance. Med Sci Sports Exerc.1998;30(4):523-8.

14. Cameron SL, McLay-Cooke RT, Brown RC, Gray AR, Fairbairn KA. Increased bloodpH but not performance with sodium bicarbonate supplementation in elite rugby unionplayers. Int I Sport Nutr Exerc Metab. 2010;20(4):307-21.
15. Siegler JC, Marshall P, Pouslen MK, Nielsen NP, Kennedy D, Green S. The effect ofpH on fatigue during submaximal isometric contractions of the human calf muscle. Eur J Appl Physiol. 2015;115(3):565-77.

16. Hunter AM, DeVito G, Bolger C, Mullany H, Galloway SDR. The effect of inducedalkalosis and submaximal cycling on neuromuscular response during sustained isometriccontraction. J Sports Sci. 2009;27(12):1261-9.

17. Maughan RJ, Leiper JB, Litchfield PE. The effects of induced acidosis and alkalosis onisometric endurance capacity in man. In: Dotson CO, Humphrey JH. editors. Exercise Physiology: current Selected Research. Vol. 2. New York: AMS Press; 1986.p.73-82.

18. Derave W, Ozdemir MS, Harris RC, Pottier A, Reyngoudt H, Koppo K, et al. Beta-alanine supplementation augments muscle carnosine content and attenuates fatigueduring repeated isokinetic contraction bouts in trained sprinters. J Appl. Physiol. 2007;103(5):1736-43.

19. Hosseninzadeh M, Andersen OK, Arendt-Nielsen L, Madeleine P. Pain sensitivity isnormalized after a repeated bout of eccentric exercise. Eur J Appl Physiol. 2013;113(10):2595-602.

20. Foster C, Florhaug JA, Franklin J, Gottschall L, Hrovatin LA, Parker S, et al. A newapproach to monitoring exercise training. J Strength Cond Res. 2001;15(1):109-15.

21. Rhea MR. Determining the magnitude of treatment effects in strength training researchthrough the use of the effect size. J Strength Cond Res. 2004;18(4):918-20.

22. Coombes J, McNaughton LR. Effects of bicarbonate ingestion on leg strength andpower during isokinetic knee flexion and extension. J Strength Cond Res. 1993;7(4):241-9.

23. Verbitsky O, Mizrahi J, Levin M, Isakov E. Effect of ingested sodium bicarbonate onmuscle force, fatigue, and recovery. J Appl Physiol. 1997;83(2):333-7.

24. Mueller SM, Gehrig SM, Frese S, Wagner CA, Boutellier U, Toigo M. Multiday acutesodium bicarbonate intake improves endurance capacity and reduces acidosis in men. J Int Soc Sports Nutr. 2013;10(16):1-9.

25. Baker JS, McCormick MC, Robergs RA. Interaction among Skeletal Muscle Metabolic Energy Systems during Intense Exercise. J Nutr Metabol. 2010;1-13.

26. Duncan MJ, Weldon A, Price MJ. The effect of sodium bicarbonate ingestion on backsquat and bench press exercise to failure. J Strength Cond Res. 2014;28(5):1358-66.

27. Amann M. Central and Peripheral Fatigue: Interaction during Cycling Exercise in Humans. Med Sci Sport Exerc. 2011;43(11):9-45. 